\title{
University buildings named on shaky ground
}

\section{Rex Dalton, San Diego}

Before his death last year, the legendary archaeologist Frank Hibben made a \$3.5million donation to the University of New Mexico to fund an extension to its renowned anthropology museum.

But as the Hibben Center for Archeological Research nears completion in Albuquerque, it is confronting a very different aspect of Hibben's legacy: his apparent faking of research over many decades.

Some faculty members at the university are using Hibben's transgressions - which have been widely publicized for years - to teach students how not to conduct themselves. Researchers in the field even refer to data contortions as 'hibbenisms'. "He thought it didn't hurt to make the evidence a little better," says Vance Haynes, an archaeologist at the University of Arizona in Tucson.

American universities constantly seek major benefactors for building projects, with staff at development offices working to bring in donations. Most contributors have had stellar careers. But sometimes donations are made by individuals or firms who are seeking legitimacy after miring themselves in controversy.

For instance, the first laboratory building at the new Mission Bay campus of the University of California, San Francisco (UCSF) is named Genentech Hall. What few of its students may realize is that the building was paid for by a \$200-million lawsuit settlement after San Franciscobased Genentech allegedly stole valuable human growth-hormone DNA from UCSF. Genentech made the payment to UCSF in 1999 without admitting any wrongdoing (see Nature 402, 335; 1999).

At the University of Arizona, meanwhile, an agricultural-science building was named in 1992 to honour land baron Kemper Marley - the reputed mastermind of the 1976 bombing murder of Don Bolles, an investigative reporter for the Arizona Republic. When Marley died, his family made a \$6-million contribution to The Marley Building, a name that still infuriates some people. "I refused to go into the building," says Don Carson, a former journalism professor at Arizona.

At Seton Hall University in South Orange, New Jersey, the name of businessman Robert Brennan, who had been convicted of fraud, was physically chiselled off a recreation centre late last year after the university decreed a revised policy for the naming of its buildings.

"These cases are rare," says Sheldon Steinbach, an attorney for the American Council on Education (ACE), which represents 1,800 academic institutions. But after a recent spate of corporate malfeasance in the United

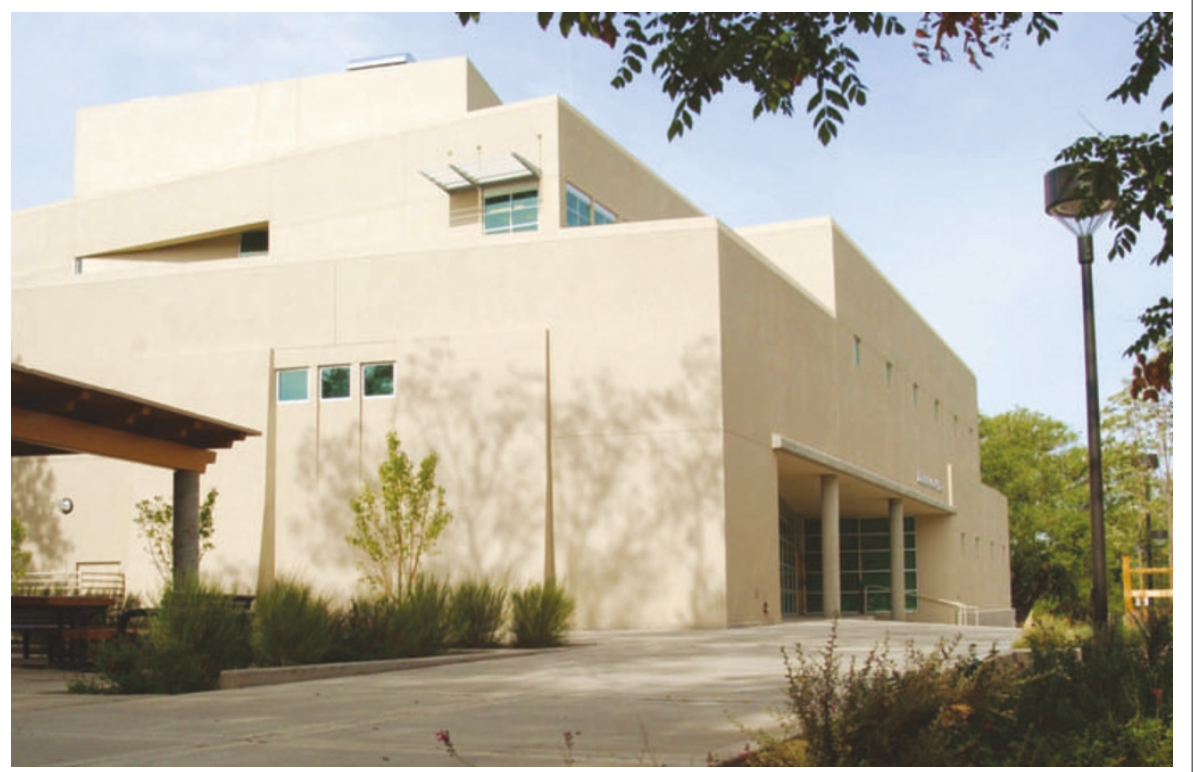

The University of New Mexico's archaeology centre honours Frank Hibben (below), who faked results.

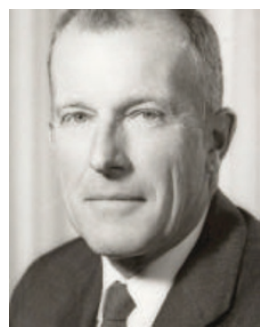

States, he says, "universities are likely to look a little more askance at large donations from sketchy sources".

Neither ACE nor the Association of American Universities, which represents top research universities in the United States and Canada, has a clear policy on building donations, because each case is so different.

The reason for Hibben's fame was his 1937 claim to have discovered undisturbed sedimentary layers showing that people lived in Sandia Cave, New Mexico, about 25,000 years ago. This is by far the earliest date claimed for an indigenous American culture.

Hibben co-founded the University of New Mexico's Maxwell Museum of Anthropology in 1932 and led it for three decades, during a golden age of discoveries in the

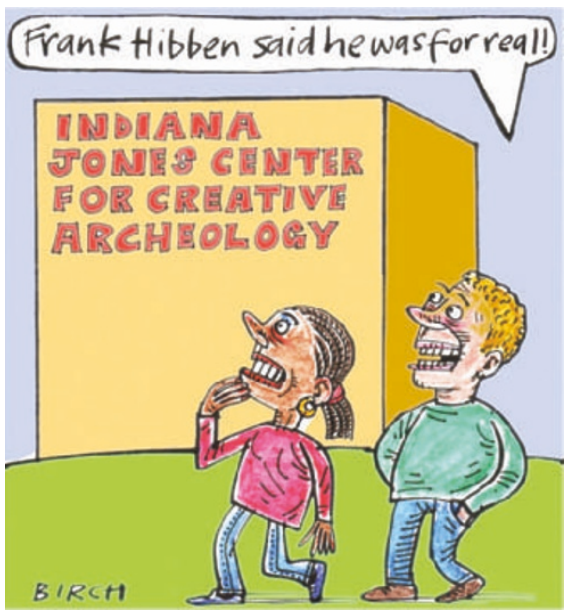

heritage-rich southwestern United States. A charismatic professor at the university, he was a mentor to many of today's leading US archaeologists, and is widely credited with popularizing modern archaeology.

Scientific publications over the past 25 years have questioned or disproved several of his most noted discoveries. His Sandia Cave claim, for example, was discredited by Haynes and others, who found the cave's rock formations to be quite different from those described by Hibben. But he was never publicly accused of scientific misconduct.

In 1946, Hibben described an expedition to Chinitna Bay on the west side of Cook Inlet in Alaska. He claimed that a geological site in the bay has lithic points that match those of the Folsom people, who are known to have lived in New Mexico 10,000 years ago.

But in 1978, when archaeologist James Dixon and others returned to the isolated location, they found Hibben's claim to be false. "It is clear that the site never existed," says Dixon, now at the University of Colorado in Boulder. In classes at the University of New Mexico, archaeologist Bruce Huckell provides articles on these interpretations to students. "Some think Hibben's work is all faked," says Huckell. "Others think we don't have enough information to know."

At UCSF, medical anthropologist Judith Barker says that she uses such cases to teach responsible research conduct. She says that she has not used the Genentech case as an example, but may yet do so. "A lot of young scholars don't understand that they don't own the research they conduct at a public university," she says. "It can be an unpleasant lesson to learn. They could learn from the Genentech case." 